\section{Notes and Records of the Royal Society}

TEE recent appearance of the April number (vol. 10, No. 2) of Notes and Records of the Royal Society of London provides an opportunity of directing general attention to this valuable periodical. Hitherto addressed mainly to Fellows, it has gradually established itself as a medium for the publication of full articles on less well-known past Fellows, and also of more detailed notices of discoveries, which have cast a new light upon already well-documented lives. With the current issue the editor is circulating an appeal to Fellows to widen the search for MS. material and to enlist the interest of others who may be engaged on research into the history of the Society or of its past Fellows. The current issue, besides containing reports on the anniversary dinner and the Ramsay centenary, naturally emphasizes Sir Hans Sloane, the bicentenary of whose death falls this year. An article on Samuel Hartlib's influence continues the valuable series of studies, by various authors, of the circumstances of the foundation of the Royal Society. Those whose interests are rather literary than scientific will also do well to keep an eye on Notes and Records : in the current number Dr. Johnson's scientific affinities are shown to have been greater than is commonly realized, and M. de Voltaire appears in an engaging light in the "Journal" of John Morgan, an American Fellow. Following an account of the outstanding Keynes Collection of Newtoniana in the previous issue, we are in the current one provided with a concise but fully catalogued summary of the archives of the Cavendish Laboratory. Notes and Records, indeed, seems admirably adapted to become one of the muchto-be-desired meeting grounds for devotees both of the natural sciences and humanities. In its finely printed pages historians will scarcely fail to find valuable material; and others, less pragmatically, perhaps even more valuable entertainment.

\section{Irish National Committee for Geodesy and Geo- physics}

Ax Irish National Committee for Geodesy and Geophysics was established in 1952 with headquarters at 44 Upper O'Connell Street, Dublin. The Committee was established in accordance with the recommendation of the International Union of Geodesy and Geophysics, of which Ireland, through the Department of Industry and Ccmmerce, has been a member since 1939. The Minister for Industry and Commerce, $\mathrm{Mr}$ Sean F. Lemass, appointed Mr. J. C. B. MacCarthy, of the Department of Industry and Commerce, to be chairman of the Committee. Represented on the Committee by one member, whose name is given in brackets, are the following institutions: Irish Meteorological Service (Dr. M. Doporto); Royal Irish Academy (Prof. J. J. Dowling); Seismological Observatory, Rathfarnham Castle (Rev. R. E. Ingram, S.J.) ; University College, Cork (Prof. J. J. McHenry); St. Patrick's College, Maynooth (Rev. P. J. McLaughlin); Ordnance Survey (Lieut.-Col. J. E. Nolan); University College, Dublin (Dr. P. J. Nolan); Geological Survey (Mr.M. V. O'Brien, director of the Survey); University College, Galway (Prof. C. O. Brolchain); Department of Agriculture (Mr. S. O. Meallain); Dublin Institute for Advanced Studies (Prof. L. W. Pollak) ; Trinity College, Dublin (Prof. J. H. J. Poole). The Committee meets about four times a year, and the matters which have so far engaged the attention of the Committee include hydrography, the Irish bibliography for hydrology, geodetic levelling and methods of accurate computation of mean sea-level for Ireland. The means by which the Committee can most effectively discharge its functions have been under consideration, and the Cormmittee or individual members thereof will welcome communications from scientific bodies or persons interested in any of the branches of science covered by the International Union.

\section{Botanical Society of Bengal}

THE seventeenth annual general meeting of the Botanical Society of Bengal was held on May 16 in the Department of Botany, University of Calcutta. Dr. R. Ahmed, Minister for Agriculture and Cooperation, Government of West Bengal, who was chief guest, spoke on the difficulty of inducing the Indian farmer to adopt the seeds, manure and equipment developed as a result of modern research. Consequently in India there is a great gap between the scientist in his laboratory and the worker in the fields. Dr. J. C. Sen Gupta, president of the Society, spoke of "Some Aspects of Recent Studies on Plant Growth Substances". In his review he recalled the considerable improvements in the field of agriculture, made possible by the application of particular hormones at particular stages in the life-history of the plant. Scme recent discoveries of certain grow: $h$ substances of root, stem, leaf and flower have been utilized in such varied aspects as the increase of fruit yield, the induction of seedless fruits, the causing of biennially fruiting trees to bear annually, the defoliation of plants, the prevention of leaf-fall, the control of weeds and the like.

Sjta. Mridula Datta, hon. secretary, presented the annual report of the Society. During the year greater interest has been aroused by holding the meetings at different centres of botany. Consequently the membership has increased. Two issues of the Bulletin have been published. The following officers were elected for 1953-54 : President, Dr. J.C. Sen Gupta; Hon. Secretary, Sjta. Mridula Datta ; Hon. Treasurer, Sri P. K. Bose ; Editor of Publications, Prof. S. R. Bose; Secretary Foreign Correspondence, Sri A. K. Ghosh : Hon. Lihrarian. Sri J. K. Sen.

\section{Specifications for Insecticides}

THE World Health Organization Expert Committee on Insecticides devoted its fourth session to a general revision of specifications for substances used in controlling insect vectors of disease. The report on this session appears as No. 54 in the World Health Organization Technical Report Series (pp. 94. London : H.M.S.O., 1953. 5s.). New standards have been adopted for the following insecticides : technical DDT, technical benzene hexachloride (BHC) and its concentrates, technical methoxychlor, technical chlordane, water-dispersible powder concentrates of DDT and of BHC, and DDT emulsion concentrates. Technical dieldrin, pyrethrum extract, and certain emulsion concentrates were among other substances considered for which standards were formulated. Throughout this work the committ ee was at pains 10 specify only one test method- the simplest possible - for the determination of a given property. Although it is as yet unable to recommend a single control-test for the determination of sedimentation-rates for most water-dispersible powders, it has perfected such a test for the dispersible-powder forms of DDT. Specifications for aerosols, diluents, solvents and emulsifiers, as well as certain data on the preservation 